\title{
LIMITAÇÃO TEMPORAL DOS MAUS ANTECEDENTES: ASPECTOS DOUTRINÁRIOS E JURISPRUDENCIAIS
}

\section{TIME LIMITS TO CRIMINALS ANTECEDENTS: DOCTRINAL AND JURISPRUDENCIAL ASPECTS}

\section{Michele Vargas ${ }^{1}$}

Resumo: Questão corriqueira no dia a dia forense, notadamente na prática criminal, é a valoração, na dosimetria da pena, dos antecedentes criminais, por força do que estatui o Código Penal. Recente julgamento de uma das Turmas do Supremo Tribunal Federal, no entanto, reacendeu o debate acerca da limitação temporal dos maus antecedentes, em analogia ao disposto no Código Penal para o instituto da reincidência, por adotar entendimento diverso daquele que tem sido endossado pelo Superior Tribunal de Justiça-embora ainda pendente de julgamento perante a Corte Suprema o recurso em que a celeuma objeto teve repercussão geral reconhecida e tornará a ser explorada. Dada a relevância da matéria, cuja divergência avança sobre a seara doutrinária, o presente artigo parte do estudo acerca da individualização da pena, dos seus momentos e sistemas propostos, com enfoque na individualização judicial da pena e do critério trifásico adotado pelo Diploma Penal. Passa, em seguida, à explanação acerca dos meandros da primeira etapa da dosimetria da pena, consistente na análise das circunstâncias judiciais, em especial sob o prisma dos antecedentes, a partir de sua conceituação, da apresentação das críticas doutrinárias que ensejam e da exposição das discussões que os permeiam. E, por fim, chega-se ao ponto central da discussão, que é a (im)possibilidade de consideração dos maus antecedentes após o transcurso do período depurador de cinco anos, com a exposição das vertentes identificadas na doutrina e nos Tribunais Superiores, consolidando-se os principais argumentos delineados.

Palavras-chave: Maus antecedentes. Limitação temporal. Doutrina. Jurisprudência.

Abstract: It is usual in criminal cases the application of antecedents in the process of fixing criminal penalties,

1 Bacharela em Direito pela Universidade Federal de Santa Catarina (UFSC). Pósgraduanda em Direito Constitucional pela Universidade Anhanguera (Uniderp) em parceria com a Rede de Ensino Luiz Flávio Gomes (LFG). Servidora do Tribunal de Justiça de Santa Catarina (TJSC). E-mail:michelevgs@gmail.com 
as established in the Penal Code. Recent trial of one of the Supreme Court classes, however, has revived the discussion about the time limits of criminals antecedents, in analogy to the provisions of the Penal Code for recidivism institute, because the Ministers had a different understanding than the usual entente of theSuperior Court of Justice - although is still pending judgment in the Supreme Court the appeal in which this object had recognized general repercussion and will be explored again. As it is an important matter, whose divergence advances on the doctrinal area, the present article starts studying the individualization of punishment, its moments and systems, focusing on judicial individualization of punishment and the systemadopted by the Penal Code. Then goes through the explanation about the first step of punishment individualization, consisting on analysis of legal circumstances, especially about the antecedents, its conceptualization, doctrinal criticism and other discussions about the matter. And finally, this study arrive at the central point of the discussion, which is the (im)possibility to consider criminal antecedents after passing the five years of recidivism, explaining the different arguments in doctrine and in Courts.

Keyword: Criminals antecedents. Time limits. Doctrine. Jurisprudence.

\section{INTRODUÇÃO}

A discussão acerca da limitação temporal dos maus antecedentes, em analogia ao que ocorre com a reincidência, por força do que estatui o art. 64, I, do Código Penal, é questão sobremaneira tormentosa atualmente tanto na doutrina, quanto na jurisprudência, lançando-se os mais diversos argumentos para a defesa de cada uma das posições existentes.

Embora não se trate de discussão recente, o julgamento pelo Supremo Tribunal Federal do Habeas Corpus n. 126.315, da Segunda Turma, de relatoria do Ministro Gilmar Mendes, em 15.9.2015, aqueceu o debate, vez que a posição que prevaleceu, conquanto por maioria, é contrária ao que de forma reiterada vem sendo decidido pelo Superior Tribunal de Justiça.

Trata-se, em verdade, de matéria relevante e delicada, que tangencia princípios e garantias constitucionais, como o da vedação às penas perpétuas, o princípio da dignidade da pessoa humana, da individualização da pena, da proporcionalidade, 
da igualdade, entre outros, além de regras infraconstitucionais já consagradas e de corriqueira aplicação no cotidiano forense.

Encontra-se pendente de julgamento perante a Corte Suprema, ademais, o Recurso Extraordinário n. 593.818, de relatoria do Ministro Luís Roberto Barroso, em que a celeuma em questão teve repercussão geral reconhecida e tornará a ser explorada, o que reforça ser de todo conveniente perscrutar o atual panorama que permeia a discussão.

O presente trabalho, que não tem por escopo traçar conclusões sobre a matéria, pretende identificar as vertentes existentes na doutrina e nas Cortes Superiores, bem assimos seus respectivos fundamentos, de forma a permitir que o leitor reúna elementos para tomar conhecimento do estágio atual da discussão e assim possa, querendo, alcançar suas próprias conclusões.

\section{A INDIVIDUALIZAÇÃO DA PENA}

A individualização da pena, uma das pedras angulares do Direito Penal contemporâneo (PRADO, 2015, p. 518), é inerente ao Estado democrático e social de Direito e está prevista, de forma expressa, na Constituição Federal, em seu art. 5', XLVI, segundo o qual "a lei regulará a individualização da pena.". Constitui, a despeito de seu regramento constitucional e penal autônomo, dimensão do princípio da proporcionalidade (QUEIROZ, 2009, p. 326).

A realização desse princípio constitucional, dá-se em três momentos distintos, conforme a lição de Bitencourt (2013, p. 767):

individualização legislativa - processo através do qual são selecionados os fatos puníveis e cominadas as sanções respectivas, estabelecendo seus limites e critérios de fixação da pena; individualização judicial - elaborada pelo juiz na sentença, é a atividade que concretiza a individualização legislativa que cominou abstratamente as sanções penais, e, finalmente, individualização executória, que 
ocorre no momento mais dramático da sanção criminal, que é o seu cumprimento.

Cumpre rememorar, ademais, que são três os sistemas doutrinariamente referidos acerca da determinação das penas (PRADO, 2015, p. 519): o sistema da absoluta determinação, também conhecido como legalismo extremo, exaure a individualização em um momento único, qual seja, o legislativo, em que a pena é fixada antecipadamente, de forma que resta ao juiz apenas a sua aplicação ao caso concreto; o sistema da absoluta indeterminação ou do livre-arbítrio judicial, segundo o qual, conforme intuitivamente se infere, ao juiz são conferidos poderes ilimitados na tarefa da determinação da pena, vez que esta não acompanha a descrição da conduta típica; por fim, tem-se o sistema da relativa indeterminação, adotado pelo Código Penal, em sua redação original e após a reforma de 1984, pelo qual são complementares as individualizações legislativa e judicial, vez que compete ao juiz a fixação discricionária da pena, em observância da espécie e dos limites indicados na legislação respectiva.

Interessa ao presente trabalho, pontue-se, a individualização judiciária da sanção penal, acerca da qual são relevantes os apontamentos de Queiroz (2009, p. 325-326):

A individualização judicial da pena - conceito que se opõe à generalização, a revelar que a sentença deve se ater tanto quanto possível ao caso concreto e evitar argumentos que transcendam a análise do comportamento do indivíduo em julgamento, sob pena de lhe conferir caráter exemplificador, generalizador, e não individualizador - é a fixação, pelo juiz, das consequências, jurídicas (pena etc.) da infração penal punível (crime ou contravenção), conforme o grau de culpabilidade do agente, aferida de acordo com as circunstâncias jurídico-penalmente relevantes. Mas a individualização não compreende apenas, como o nome pode sugerir, a fixação da pena mesma, mas também o reconhecimento de causas de isenção de pena (concessão de perdão e escusas absolutórias etc.), bem assim a aplicação de me- 
didas de segurança e dos efeitos secundários da condenação. Individualizar a pena significa assim tornar individual uma situação, algo ou alguém, isto é, particularizar o que antes era geral, e evitar a estandardização.

Para a tarefa consistente na dosimetria da pena são propostos dois modelos.

No primeiro deles, o sistema bifásico, idealizado por Roberto Lyra, ao juiz compete, primeiramente, fixar a pena-base a partir do exame das circunstâncias judiciais, bem como das agravantes e atenuantes, de forma concomitante, e, em um segundo momento, cumpre-lhe apreciar as causas de aumento ou diminuição previstas. Já o segundo, de Nélson Hungria, concebe três etapas - por isso chamado trifásico -, sendo a primeira a fixação da pena base, com espeque nas circunstâncias judiciais; a segunda está atrelada às circunstâncias agravantes e atenuantes; e, ao cabo, tem-se a consideração das causas de aumento e diminuição, sejam elas gerais ou especiais (PRADO, 2015, p. 525).

O Código Penal, é consabido, filiou-se ao critério trifásico - inaplicável, entretanto, à pena de multa, para o qual encampou o sistema bifásico (art. 49, caput e $\S 1^{\circ}$ ) -, eis que seu art. 68 preconiza que "A pena-base será fixada atendendo-se ao critério do art. 59 deste Código; em seguida, serão consideradas as circunstâncias atenuantes e agravantes; por último, as causas de diminuição e de aumento.". Em cada etapa, incumbe ao magistrado decidir de forma fundamentada, com o que se concretizará a individualização da pena e se permitirá o exercício da ampla defesa (art. 5 , LV, da Constituição Federal) (MASSON, 2016, p. 718).

\section{A PRIMEIRA ETAPA DA DOSIMETRIA E OS ANTECEDENTES}

Com o escopo de permanecer nos limites do objeto do pre- 
sente estudo, volta-se, especificamente, à primeira etapa da fixação da pena, que consiste no exame das circunstâncias judiciais.

Tem-se a sua previsão legal no art. 59 do Código Penal, que estatui que o juiz fixará as penas aplicáveis, a sua quantidade dentro dos limites previstos, o regime inicial de cumprimento da pena privativa de liberdade e a sua substituição por outra espécie cabível "atendendo à culpabilidade, aos antecedentes, à conduta social, à personalidade do agente, aos motivos, às circunstâncias e consequências do crime, bem como ao comportamento da vítima", consoante se afigure necessário e suficiente para reprovação e prevenção do crime.

São, na verdade, dados ou fatos, de ordem subjetiva ou objetiva, que orbitam o crime, interferindo em sua pena, mas a sua ausência, porquanto não lhe são essenciais, não exclui o tipo penal (DELMANTO, 2007, p. 185). Bitencourt (2013, p. 768), a propósito, esclarece que

Os elementos constantes do art. 59 são denominados circunstâncias judiciais, porque a lei não os define e deixa a cargo do julgado a função de identificá-los no bojo dos autos e mensurá-los concretamente. Não são efetivas "circunstâncias do crime", mas critérios limitadores da discricionariedade judicial, que indicam o procedimento a ser adotado na tarefa individualizadora da pena-base.".

Tais circunstâncias judiciais, destaque-se, apenas têm lugar quando não constituírem elementos do tipo, qualificadoras ou privilégios, agravantes ou atenuantes genéricas, bem ainda causas de aumento ou diminuição, ou seja, possuem caráter residual ou subsidiário, considerando-se que as demais indicadas detêm preferência porque previstas em lei, e não sujeitas ao arbítrio judicial.

Dentre as circunstâncias judiciais elencadas, consoante observado, encontram-se os antecedentes, que, nas palavras de Nucci (2015, p. 432), 
Trata-se de tudo o que existiu ou aconteceu, no campo penal, ao agente antes da prática do fato criminoso, ou seja, sua vida pregressa em matéria criminal. Antes da Reforma de 1984, podia-se dizer que os antecedentes do réu abrangiam todo o passado do réu, desde as condenações porventura existentes até seu relacionamento na família ou no trabalho. Atualmente, no entanto, terminou sendo esvaziado este último requisito, merecendo circunscrever sua abrangência à folha de antecedentes.

Tal circunstância judicial, sobreleva notar, não é imune às críticas doutrinárias.

Com efeito, uma vez que a sua finalidade está voltada à demonstração da maior ou menor afinidade do réu com a prática de delitos (BITENCOURT, 2013, p. 769), há quem vislumbre na sua previsão resquício do direito penal do autor, vez que, para além do exame dos fatos, ingressa-se na aferição da vida pregressa do agente.Pacelli e Callegari (2015, p. 491), a respeito, ponderam:

Naturalmente que qualquer juízo que se queira fazer sobre o agente, para além de sua culpabilidade pelo fato, incorrerá em tais riscos. Por isso, o critério que nos parece decisivo para a aceitação ou não dos fatos passados, como critério de fixação da pena, é, ao lado da previsão legal (princípio da legalidade), a observância do devido processo legal me que se possa, de fato, afirmar-se, com convicção, a responsabilidade pelo fato a ser considerado.

Há autores, ainda, que consideram a valoração dos antecedentes incompatível com os princípios que regem o direito penal democrático e humanitário, por configurar uma agravação a mais para a condenação anterior, e que o identificam como instrumento de discriminação social, de verdadeira diversificação dos criminosos dos demais seres humanos (ALMEIDA, 2009, p. 332-333).

A discussão a respeito do que é capaz de configurar maus antecedentes e, por conseguinte, acarretar a elevação da pena- 
-base não é, nem de longe, tranquila.

Para a corrente tradicional, podem ser enquadrados como maus antecedentes os inquéritos instaurados, processos criminais não transitados em julgado e que não constituem reincidência, absolvições por falta de provas, extinção do processo com fundamento em prescrição, seja ela abstrata, retroativa ou intercorrente. Para a corrente crítica, no entanto, a única compreensão compatível com o princípio constitucional da presunção de inocência é a de que apenas configuram maus antecedentes condenações criminais definitivas que não configuram reincidência (SANTOS, 2008, p. 571).

A respeito da utilização de inquéritos e ação penal em curso como maus antecedentes, observa-se que, atualmente, doutrina e jurisprudência majoritárias a rechaçam por implicar, efetivamente, violação à presunção de inocência.

Ora, se a Carta Magna estatui, em seu art. 50, LVII, que "ninguém será considerado culpado até o trânsito em julgado de sentença penal condenatória”, considerá-los para tal fim significa impor uma condenação reflexa, permitindo-se de forma indireta o que a lei proíbe diretamente (QUEIROZ, 2009, p. 344-345). Não é de outra forma que entendem Rogério Greco (2016, p. 681-682), Delmanto e outros (2007, p. 187) e Santos (2008, p. 571), dentre outros.

A propósito, parece ter sido essa a orientação do parágrafo único do art. 20 do Código de Processo Penal, com a redação dada pela Lei n. 12.681/2012, segundo a qual "Nos atestados de antecedentes que lhe forem solicitados, a autoridade policial não poderá mencionar quais anotações referentes a instauração de inquérito contra os requerentes.".

O Supremo Tribunal Federal, após alguma oscilação, tem entendido de igual modo. No julgamento, pelo plenário, do Recurso Extraordinário n. 591.054/SC, em 17.12.2014, de re- 
latoria do Ministro Marco Aurélio, conforme noticiado no Informativo n. 772, decidiu-se que:

O Colegiado explicou que a jurisprudência da Corte sobre o tema estaria em evolução, e a tendência atual seria no sentido de que a cláusula constitucional da não culpabilidade (CF, art. $5^{\circ}$, LVII) não poderia ser afastada. Haveria semelhante movimento por parte da doutrina, a concluir que, sob o império da nova ordem constitucional, somente poderiam ser valoradas como maus antecedentes as decisões condenatórias irrecorríveis. Assim, não poderiam ser considerados para esse fim quaisquer outras investigações ou processos criminais em andamento, mesmo em fase recursal. Esse ponto de vista estaria em consonância com a moderna jurisprudência da Corte Interamericana de Direitos Humanos e do Tribunal Europeu dos Direitos do Homem. Ademais, haveria recomendação por parte do Comitê de Direitos Humanos das Nações Unidas, no sentido de que o Poder Público deveria abster-se de prejulgar o acusado.

No Superior Tribunal de Justiça, de sua feita, essa posição restou consolidada no Enunciado n. 444, que estabelece que "É vedada a utilização de inquéritos policiais e ações penais em curso para agravar a pena-base.".

Mas se essa questão, nos dias atuais, caminha de forma mais tranquila, o mesmo não se pode dizer a respeito da necessidade de observância, ou não, do prazo depurador de cinco anos previsto no art. 64, I, do Código Penalpara a utilização de condenações anteriores para fins de maus antecedentes.

\section{A LIMITAÇÃO TEMPORAL DOS MAUS ANTECEDENTES}

A reincidência, agravante a ser considerada na segunda etapa da dosimetria da pena (art. 61, I, do Código Penal), submete-se, consoante ressabido, ao sistema da temporariedade, tendo em vista o teor do art. 64, I, do Código Penal, segundo o qual "não prevalece a condenação anterior, se entre a data 
do cumprimento ou extinção da pena e a infração posterior tiver decorrido período de tempo superior a 5 (cinco) anos, computado o período de prova da suspensão ou do livramento condicional, se não ocorrer revogação.". Esse sistema tem por escopo evitar que uma condenação criminal permaneça de forma perpétua na vida do agente, pelo que limita os seus efeitos no tempo (CAPEZ, 2016, p. 481).

Questiona-se, então, se também os maus antecedentes devem se submeter a tal período depurador ou se, ao contrário, esse lapso temporal não tem o condão de eliminar indigitada circunstância desabonadora.

Capez (2016, p. 481-482) identifica, nesse particular, duas correntes: para a primeira, as condenações anteriores ao período de cinco anos continuam a gerar maus antecedentes, de forma que, embora não seja possível configurar a reincidência, por força do que dispõe o art. 64, I, do Código Penal, é possível sua consideração na dosimetria da pena; já para a segunda corrente, estende-se o critério do mencionado dispositivo aos maus antecedentes, porquanto que seria destituído de lógica afastar de forma expressa a agravante, mas continuar a permitir, de forma genérica, o recrudescimento da sanção, além de que, uma vez quitada a obrigação do agente com a justiça penal, o estigma da condenação criminal não pode ser perpétuo, devendo, portanto, ser limitado no tempo.

Na doutrina, Masson (2016, p. 727) entende que o Código Penal teria se filiado ao sistema da perpetuidade para os maus antecedentes por ausência de regra análoga à existente para a reincidência, de maneira que "o decurso do tempo após o cumprimento ou extinção da pena não elimina esta circunstância judicial desfavorável, ao contrário do que se verifica na reincidência.”.

Para Capez (2016, p. 482), a condenação que caducou para fins de reincidência continua válida para gerar maus antece- 
dentes. Pondera o doutrinador, contudo, que "É claro que com o passar do tempo, os processos e condenações anteriores vão perdendo a influência sobre a pena de futuros crimes, mas, de acordo com as peculiaridades de cada caso concreto, não se podendo falar em prazo fixo de prescrição.”.

Compreende Nucci (2015, p. 433-434) que "O período depurador relativo à reincidência (art. $64, \mathrm{I}, \mathrm{CP})$, de cinco anos, justifica-se porque essa circunstância acarreta vários gravames ao acusado/condenado. Eis o motivo pelo qual há um prazo para caducar". Reputa, assim, que os maus antecedentes não se submetem a esse lapso temporal, mas considera que, tratando-se de circunstância judicial, devem ser avaliados no caso concreto, de forma a aferir se possuem conexão com o crime perpetrado, o que exemplifica do seguinte modo:

Ilustrando, se o réu apresenta um antecedente antigo de lesão corporal, nem esse fato não merece ser considerado na fixação da pena, caso seja condenado por estelionato. Por outro lado, mesmo passados alguns anos, se o acusado foi anteriormente sentenciado por homicídio e torna a cometer um crime violento contra a pessoa, deve-se levá-lo em consideração.

Costa (2007, p. 408), na toada dos demais, também compreende que, após o lapso de cinco anos, as condenações transitadas em julgado configuram maus antecedentes.

O entendimento do Superior Tribunal de Justiça,saliente-se, coloca-se nessa direção. Confira-se, a título ilustrativo, o seguinte julgado da sua Quinta Turma:

HABEAS CORPUS SUBSTITUTIVO DE RECURSO PRÓPRIO. INADEQUAÇÃO DA VIA ELEITA. RESISTÊNCIA E DESACATO.DOSIMETRIA. MAUS ANTECEDENTES. CONDENAÇÕES CRIMINAIS COM MAIS DE 5 ANOS. CONFIGURAÇÃO DE MAUS ANTECEDENTES. POSSIBILIDADE. CONFISSÃO EXTRAJUDICIAL. INCIDÊNCIA DA ATENUANTE. 
SUBSTITUIÇÃO DA PENA PRIVATIVA DE LIBERDADE. NÃO PREENCHIMENTO DOS REQUISITOS DO ART. 44 DO CP. VIOLÊNCIA E GRAVE AMEAÇA. HABEAS CORPUS NÃO CONHECIDO. ORDEM CONCEDIDA DE OFÍCIO.

$[\ldots]$

- Nos termos da jurisprudência desta Corte Superior, as condenações criminais alcançadas pelo período depurador de 5 anos, previsto no art. 64, inciso I, do Código Penal, afastam os efeitos da reincidência, contudo, não impedem a configuração de maus antecedentes, autorizando o aumento da pena-base acima do mínimo legal.

[...](Habeas Corpus n. 362.654/SP. Relator Ministro Reynaldo Soares da Fonseca, Quinta Turma, julgado em 5.5.2016).

Ainda: Recurso Ordinário em Habeas Corpus n. 66.436/ SP. Relator Ministro Felix Fischer, Quinta Turma, julgado em 12.4.2016; e Habeas Corpus n. 338/967/SP. Relator Ministro Nefi Cordeiro, Sexta Turma, julgado em 18.2.2016.

Merece destaque, por pertinente, recente julgado da Sexta Turma, no qual, apesarde seguir o entendimento pacífico da Corte Superior, afastou da dosimetriaa consideração dos maus antecedentes com base em peculiaridades do caso concreto-na toada, aliás, do que defendem os doutrinadores anteriormente referidos. Confira-se:

RECURSO ESPECIAL. TRÁFICO DE DROGAS. CAUSA ESPECIAL DE DIMINUIÇÃO DE PENA. MAUS ANTECEDENTES. PERÍODO DEPURADOR. FRAÇÃO DA MINORANTE. FUNDAMENTAÇÃO CONCRETA. RECURSO NÃO PROVIDO.

1. Consoante entendimento deste Superior Tribunal, decorrido o prazo de cinco anos entre a data do cumprimento ou a extinção da pena e a infração posterior, a condenação anterior, embora não possa prevalecer para fins de reincidência, pode ser sopesada a título de maus antecedentes. Precedentes. 
2. Sem embargo, não há como afastar a aplicação da minorante prevista no $\S 4^{\circ}$ do art. 33 da Lei de Drogas pela simples existência de duas condenações transitadas em julgado com extinção da punibilidade há tanto tempo, máxime porque, além de o recorrido ser tecnicamente primário ao praticar o crime em comento, não há notícias de que se dedique a atividades delituosas ou de que integre organização criminosa.

3. Se o transcurso do tempo impede que condenações anteriores configurem reincidência, esse mesmo fundamento-o lapso temporal-deve ser sopesado na análise das condenações geradoras, em tese, de maus antecedentes.

4. Embora o Supremo Tribunal Federal ainda não tenha decidido o mérito do RE n. 593.818 RG/SC-que, em repercussão geral já reconhecida (DJe 3/4/2009), decidirá se existe ou não um prazo limite para se sopesar uma condenação anterior como maus antecedentes -, no caso, firme na ideia que subjaz à temporalidade dos antecedentes criminais, devem ser relativizados os dois registros penais tão antigos do acusado, de modo a não lhes imprimir excessivo relevo a ponto de impedir a incidência da minorante descrita no $\S 4^{\circ}$ do art. 33 da Lei de Drogas.

[...] (Recurso Especial n. 1160440/MG. Relator Ministro Rogério Schietti Cruz, Sexta turma, julgado em 17.3.2016).

Do seu corpo, por pertinente, colhe-se:

Saliento - frise-se - que não estou afirmando que o mero decurso do período depurador da reincidência seja suficiente para, por si só, impedir toda e qualquer valoração sobre os antecedentes, até porque a hipótese prevista no art. 64, I, do Código Penal trata tão somente da reincidência. Da mesma forma, não estou, simplesmente, descuidando de observar o entendimento desta Corte de que condenações prévias, com trânsito em julgado há mais de 5 anos, apesar de não ensejarem reincidência, podem servir de alicerce para valoração desfavorável dos antecedentes.

Contudo, considero que eternizar a valoração negativa dos antecedentes para afastar a minorante em questão, sem nenhuma ponderação sobre as circunstâncias do caso concre- 
to, não se coaduna com o Direito Penal do fato.

Apesar de a análise dos julgados do Supremo Tribunal Federal ser objeto de exame a seguir, afigura-se conveniente desde jáconsignar que o posicionamento da Ministra Cármen Lúcia - no que acompanhada pelo Ministro Teori Zavascki -, no importante julgamento do Habeas Corpus n. 126.315/SP, de relatoria do Ministro Gilmar Mendes, é no sentido de que condenações anteriores ao período de cinco anos podem, sim, ser valoradas como maus antecedentes, eis que considera que não se deve submeter o Direito Penal a fórmulas "hermeticamente cerradas".

Para ela, a sua "aplicação deverá observar o caso concreto, tendo em vista a individualidade do ser humano e dos atos por ele praticados, os quais são submetidos à apreciação do Poder Judiciário, tornando inviável efetuar cortes lineares para a incidência das normas jurídico-penais.".Demais disso, considera que "O reconhecimento da possibilidade de utilização das condenações anteriores como maus antecedentes não configura a alegada pena perpétua, mas a consideração de situação fática da vida do Paciente, com reflexo na dosimetria penal.".

Após a exposição das lições daqueles que encampam essa primeira vertente, afigura-se autorizado concluir que não admitem a submissão dos maus antecedentes ao lapso temporal de cinco anos, em analogia ao disposto no artigo 64, I, do Código Penal, pelas seguintes razões: a um, prevista regra específica para a reincidência, não se ocupou o legislador dos maus antecedentes, que, no entanto, permanecem no rol das circunstâncias judiciais a serem valoradas na dosimetria da pena;a dois, a previsão relativa à reincidência tem sua razão de ser nos diversos efeitos gravosos dela decorrentes previstos no ordenamento jurídico - o que não ocorre, em idêntica extensão, com os maus antecedentes; a três, longe de caracterizar perpetuidade da pena, dá concretude à sua individualização, princípio que 
veda a equiparação entre acusado jamais condenado criminalmente e aquele condenado definitivamente por fatos anteriores ao quinquênio legal. No entanto,entendem, como visto, que compete ao juiz, quando da exame da hipótese em concreto, lançar mão da razoabilidade no momento da apreciação das condenações passadas na dosimetria do novo crime, de forma a aferirse são hábeis a configurar, efetivamente, a afinidade do réu com a prática delituosa.

De outro lado, tem-se aqueles favoráveis à limitação temporal dos maus antecedentes.

Queiroz (2015, p. 345) pontua que é comum considerar como maus antecedentes a própria reincidência, desde que escoado o prazo depurador de cinco anos. Considera tal proceder, no entanto, ilegítimo "porque se está ainda a utilizá-la, embora com nome diverso, em afronta ao princípio da legalidade das penas. Ademais, se não se pode o mais (aumento pela reincidência), não se pode o menos (aumento por maus antecedentes).”.

Bitencourt (2013, p. 770-771), assim como SANTOS (2008, p. 572), defende a limitação temporal dos maus antecedentes a partir da analogia com a previsão legal existente para a reincidência:

Convém destacar, ademais, a necessidade de respeitar a limitação temporal dos efeitos dos "maus antecedentes", adotando-se o parâmetro previsto para os "efeitos da reincidência" fixado no art. 64 do CP, em cinco anos, com autorizada analogia. Advogando a mesma tese, sustenta Salo de Carvalho, in verbis: "o recurso à analogia permite-nos limitar o prazo de incidência dos antecedentes no marco dos cinco anos - delimitação temporal da reincidência -, visto ser a única orientação permitida pela sistemática do Código Penal.

Nesse cenário, em que se afasta a possibilidade de considerar como maus antecedentes as condenações anteriores a cinco 
anos, poder-se-ia questionar, então, que tal vertente termina por esvaziar o conteúdo da previsão dos antecedentes no art. 59 do Código Penal, já que, em uma primeira análise, nada restaria para ser valorado a tal título. Delmanto e outros(2007, p. 187), que adotam essa orientação por considerar inconsistente limitar a reincidência e, ao mesmo tempo, permitir a sua consideração enquanto maus antecedentes, esclarecem:

Condenação transitada em julgado antes do novo fato que está sendo julgado (...) Caso o prazo depurador de cinco anos (CP, art. 64, I) já tenha passado antes do cometimento do novo crime, não deve igualmente ser considerada nos antecedentes, pois não seria coerente que a condenação anterior, não gerando mais reincidência, passasse a ser considerada como mau antecedente. Condenação por fato anterior, transitada em julgado após o novo fato: Embora não gere reincidência, sendo o acusado, como se costuma dizer de forma imprópria, "tecnicamente primário", pode ser considerada como mau antecedente. Esta, a nosso ver, em face da garantia constitucional da presunção de inocência, é hoje a única hipótese que pode ser considerada como mau antecedente.

Para Almeida (2009, p. 340), deve-se utilizar a analogia in bonam partem, com o escopo de delimitar a amplitude temporal dos antecedentes criminais, de maneira que, além de se oportunizar que a pessoa readquira a condição de primária, permita-se que ela torne ao status de sem antecedentes, vez que o indivíduo já quitou sua pendência com a sociedade. Para ele, desse modo:

Observando-se os ditames dos princípios constitucionais e, procedendo-se conforme estabelecido alhures, estar-se-á humanizando o direito criminal, de modo a cumprir, como já exposto, o fim da norma penal, que é o social e as exigências do bem comum, além de, principalmente, levar em consideração o respeito à dignidade da pessoa humana, que não pode ficar ameaçada ad perpetuam, de maneira confusa, quanto ao escorregadio passado do agente, pois o tempo é um modo 
de dissolver o direito, ou também de adquiri-lo - tempus est modus veldissolvendi jus / est modus acquirendi jus.

Questiona-se, com efeito, que se o tempo é capaz de extinguir a própria pretensão punitiva do Estado, por que não teria o condão de afastar os maus antecedentes. Leite Filho (2000, p. 492) destaca que o decurso de lapso temporal alcança a decadência, a prescrição, a perempção, etc. Pondera, com isso, que "Pelo tempo o direito morre, pelo tempo o direito se adquire. Há de se considerar, também, que não pode um deslize na vida de uma pessoa ser capaz de fazer com que ela carregue para sempre a pecha de uma imorredoura consequência.”.

Busato (2008, p. 313-314) compreende que considerar as condenações pretéritas como antecedentes incapazes de configurar reincidência vai de encontro ao sistema ressocializadorno que destaca a reabilitação-, colocando o réu em infindável confusão, vez que ora o sistema repressor considera que o fato criminoso anterior, cuja pena já foi cumprida há muito, não pode representar uma marca em seu passado e ora o retoma para fins de agravar a sua pena. A propósito, salienta:

É ilegal a utilização, em desfavor do condenado, a efeitos de fixação de pena, dos registros de condenações precedentes, não configuradoras de reincidência. Isto porque uma providência assim contrapõe-se à proposta legislativa que fulcra $o$ próprio sistema de penas, já que, uma vez reinserido socialmente o sujeito, a ponto de considerar-se criminalmente reabilitado, não é possível pretender uma distensão, a posteriori, de um desvalor social teoricamente superado.

Nos Tribunais, embora não de forma uníssona, tem-se decisões recentes da Corte Suprema a endossar tal posição, o que, conforme assinalado, aqueceu a discussão.

Antes de prosseguir, deve-se destacar que essa temática teve a sua repercussão geral reconhecida, em 2009, no Recurso Extraordinário n. 593.818, de relatoria do então Ministro 
Joaquim Barbosa - e que atualmente se encontra sob a relatoria do Ministro Luís Roberto Barroso -, mas ainda não foi submetida a julgamento.

No Habeas Corpus n. 126.315/SP, de relatoria do Ministro Gilmar Mendes, julgado em 15.9.2015 pela Segunda Turma, assim decidiu a Corte Suprema, por maioria:

Habeas corpus. 2. Tráfico de entorpecentes. Condenação. 3. Aumento da pena-base. Não aplicação da causa de diminuição do $\S 4^{\circ}$ do art. 33, da Lei 11.343/06. 4. Período depurador de 5 anos estabelecido pelo art. 64, I, do CP. Maus antecedentes não caracterizados. Decorridos mais de 5 anos desde a extinção da pena da condenação anterior $(\mathrm{CP}$, art. 64, I), não é possível alargar a interpretação de modo a permitir o reconhecimento dos maus antecedentes. Aplicação do princípio da razoabilidade, proporcionalidade e dignidade da pessoa humana. 5. Direito ao esquecimento. 6. Fixação do regime prisional inicial fechado com base na vedação da Lei 8.072/90. Inconstitucionalidade. 7. Ordem concedida.

Do voto do Relator, extraem-se importantes razões de decidir. Em primeiro lugar, considera que a ratio legis do art. 64, I, do Código Penal, conquanto se refira apenas à reincidência, é a de apagar da vida do indivíduo os erros do seu passado, tendo em conta o cumprimento da punição, já que não se pode admitir que a condenação ostente status perpétuo, o que vulneraria princípios constitucionais e legais, notadamente o da ressocialização da pena. Em segundo, a Constituição Federal proíbe as penas de caráter perpétuo - como é a tendência dos textos constitucionais, aliás -, mas a consideração dos antecedentes de forma negativa implica, precisamente, a vedada perpetuidade, ainda que revestida de legalidade. Em terceiro, tal agravamento da pena-base não encontra previsão legal ou constitucional, pelo que representa analogia in malam partem. Em quarto, assiste ao sujeito o direito ao esquecimento - direito com assento também na esfera penal, eis que é corolário 
da vedação às penas perpétuas e dos princípios da dignidade da pessoa humana, da igualdade, da proporcionalidade e da razoabilidade. Por oportuno, confiram-se alguns excertos:

Com efeito, é assente que a ratio legis consiste em apagar da vida do indivíduo os erros do passado, considerando que já houve o devido cumprimento da punição, sendoinadmissível que se atribua à condenação o status de perpetuidade, sob pena de violação aos princípios constitucionais e legais, sobretudo o da ressocialização da pena.

A Constituição Federal veda expressamente, na alínea $b$ do inciso XLVII do artigo $5^{\circ}$, as penas de caráter perpétuo. Tal dispositivo suscita questão acerca da proporcionalidade da pena e de seus efeitos para além da reprimenda corporal propriamente dita.

Ora, a possibilidade de sopesarem-se negativamente antecedentes criminais, sem qualquer limitação temporal ad aeternum, em verdade, é pena de caráter perpétuo mal revestida de legalidade.

Nessa perspectiva, por meio de cotejo das regras basilares de hermenêutica, constata-se que, se houve o objetivo primordial de afastar a pena perpétua, reintegrando o apenado no seio da sociedade, com maior razão deve-se aplicar tal raciocínio aos maus antecedentes.

Advirto, outrossim, que o agravamento da pena-base com fundamento em condenações transitadas em julgado há mais de cinco anos não encontra previsão na legislação, tampouco em nossa Carta Maior, tratando-se de analogia in malam partem, método de integração vedado no ordenamento jurídico. É que, em verdade, assiste ao indivíduo o "direito ao esquecimento", ou "direito de ser deixado em paz", alcunhado, no direito norte-americano de "therighttobeletalone".

$\mathrm{O}$ direito ao esquecimento, a despeito de inúmeras vozes contrárias, também encontra respaldo na seara penal, enquadrando-se como direito fundamental implícito, corolário da vedação à adoção de pena de caráter perpétuo e dos princípios da dignidade da pessoa humana, da igualdade, da proporcionalidade e da razoabilidade.

O Relator foi acompanhado pelo Ministro Dias Toffolie 
pelo Ministro Celso de Mello, para quem, após o transcurso do quinquênio, "não há como reconhecer nem como admitir que continuem a subsistir, residualmente, contra o réu, os efeitos negativos resultantes de condenações anteriores, a significar, portanto, que se mostrará ilegal qualquer valoração desfavorável ao acusado que repercuta, de modo gravoso, na operação de dosimetria penal[...].”.

Vencidos, como alhures salientado, a Ministra Cármen Lúcia e o Ministro Teori Zavascki.

Além desse julgado, é pertinente transcrever o teor do voto do Ministro Dias Toffoli no Habeas Corpus n. 119.200/PR, de sua Relatoria, julgado pela Primeira Turma, em 11.2.2014:

Com efeito, a interpretação do disposto no inciso I do art. 64 do Código Penal deve ser no sentido de se extinguirem, no prazo ali preconizado, não só os efeitos decorrentes da reincidência, mas qualquer outra valoração negativa por condutas pretéritas praticadas pelo agente.

Penso que eventuais deslizes na vida pregressa do sentenciado que não tenha, há mais de cinco anos, contados da extinção de pena anterior que lhe tenha sido imposta, voltado a delinquir, não podem mais ser validamente sopesados como circunstâncias judiciais desfavoráveis (CP, art. 59), sob pena de perpetuação de efeitos que a lei não prevê e que não se coadunam com os princípios constitucionais da dignidade da pessoa humana, da proporcionalidade e do caráter socializador da reprimenda penal.

Como adverte Willis Santiago Guerra Filho (Dignidade humana, princípio da proporcionalidade e teoria dos direitos fundamentais, p. 313), referido por Guilherme de Souza Nucci in Princípios constitucionais penais e processuais penais. São Paulo: RT, 2010. p. 213), "um marco histórico para o surgimento desse tipo de formação política costuma-se apontar na Carta Magna inglesa, de 1215, na qual aparece com toda clareza manifestada a ideia acima referida quando estabelece: 'o homem livre não deve ser punido por um delito menor, senão na medida desse delito, e por um 
grave delito ele deve ser punido de acordo com a gravidade do delito".

O homem não pode ser penalizado eternamente por deslizes em seu passado, pelos quais já tenha sido condenado e tenha cumprido a reprimenda que lhe foi imposta em regular processo penal.

Faz ele jus ao denominado "direito ao esquecimento", não podendo perdurar indefinidamente os efeitos nefastos de uma condenação anterior, já regularmente extinta.

Por isso, delimitou expressamente o legislador o prazo de cinco (5) anos para o desaparecimento dos efeitos da reincidência (CP, art. 64).

Se essas condenações não mais se prestam para o efeito da reincidência, que é o mais, com muito maior razão não devem valer para os antecedentes criminais, que são o menos.

No mérito, saliente-se, o julgamento - de que participaram os Ministros Luís Roberto Barroso, Rosa Weber, Luiz Fux e Marco Aurélio, foi unânime.

Além dos já mencionados, há os seguintes julgados na mesma direção: Recurso Ordinário em Habeas Corpus n. 118977/ MS, Relator Ministro Dias Toffoli, Primeira Turma, julgado em 18.3.2014; e Habeas Corpusn. 110191/RJ, Relator Ministro Gilmar Mendes, Segunda Turma, julgado em 23.4.2013.

Como é possível observar, essa segunda vertente se assenta em algumas precípuas razões. A um, uma vez proibido o agravamento da pena com base na reincidência, que é o mais grave, é incoerente permitir o aumento de pena com base nos antecedentes, já que, além de não contar com previsão legal, quem não pode o mais, não pode o menos. A dois, é hipótese, então, de se lançar mão de analogia in bonam partem e aplicar o limite temporal previsto no art. 64, I, do Código Penal também para os maus antecedentes; A três, o tempo produz diversos efeitos relevantes no Direito, e não há motivos para excepcionar os maus antecedentes. A quatro, considerar as 
condenações pretéritas de forma ilimitada representa afronta à vedação constitucional às penas perpétuas, que tem por escopo, ademais, a ressocialização do apenado. A cinco, assiste ao indivíduo o direito ao esquecimento, de forma a dar concretude aos princípios da dignidade da pessoa humana, da proporcionalidade e da razoabilidade.

\section{CONCLUSÃO}

A limitação temporal dos maus antecedentes é questão complexa e delicada, porquanto envolve discussões relevantes de índole constitucional e penal.Ambas as vertentes identificadas, como visto,servem-se de razoáveis e defensáveis argumentos.

De um lado, prioriza-se o princípio constitucional da individualização da pena, evitando-se a equiparação daquele jamais condenado com aquele com condenações em seu passado, notadamente na ausência de limitação legal específica direcionada aos maus antecedentes - na toada do que ocorre com a reincidência, que tem sua razão de ser nos gravosos efeitos dela decorrentes -, sem prejuízo de que o magistrado, com suporte na razoabilidade, avalie as condenações passadas na dosimetria do novo crime cometido, de forma a aferir se representam, efetivamente, a afinidade do réu com a prática delituosa.

De outro, dá-se ênfase na incoerência que representa afastar o recrudescimento da pena com base na reincidência, mas o permiti com suporte nos maus antecedentes, de forma a justificar a aplicação do limite temporal de cinco anos, por analogia, do art. 64, I, do Código Penal. Ademais, vislumbra-se que não há razões para que os maus antecedentes fiquem imunes aos efeitos do tempo, que atingem até mesmo a pretensão punitiva estatal, sob pena de se conferir à condenação a perpetuidade constitucionalmente vedada ( $\operatorname{art} .5^{\circ}$, XLVII, $b$, da Constituição Federal), em detrimento à ressocialização do apenado. Lança mão tal corren- 
te, ainda, da atual discussão acerca do direito ao esquecimento, o que faz com o intuito de prestigiar os princípios da dignidade humana, da proporcionalidade e da razoabilidade.

Os recentes julgamentos das Corte Superiores, notadamente a divergência destacadano Supremo Tribunal Federal, aliados aos apontamentos doutrinários, vêm, de forma benéfica, dar o destaque necessário à matéria, a fim de que se permita, de forma qualificada, uma discussão mais aprofundada acerca de seus termos, razões e consequências, evitando-se, assim, reproduções inadvertidas acerca do tema em comento.

\section{REFERÊNCIAS}

ALMEIDA, Hugo Trapp Gonçalves de. Antecedentes criminais: uma sanção criminológica de caráter perpétuo. Revista da ESMESC-Escola Superior da Magistratura do Estado de Santa Catarina, Florianópolis , v.16, n. 22, p. 311-343, jan./dez. 2009.

BITTENCOURT, Cezar Roberto. Tratado de direito penal: parte geral. 19. Ed. São Paulo: Saraiva, 2013.

BRASIL. Decreto-Lei n. 2.848 (Código Penal), de 7 de dezembrode 1940.

. Decreto-Lei n. 3.689 (Código de Processo Penal), de 3 de outubro de 1941.

. Supremo Tribunal Federal. Recurso Extraordinário n. 593.818/SC. Relator

Ministro Joaquim Barbosa, julgado em 26.2.2009.

. Supremo Tribunal Federal. Habeas Corpusn. 110.191/RJ. Relator Ministro Gilmar Mendes, Segunda turma, julgado em 23.4.2013.

. Supremo Tribunal Federal. Habeas Corpusn. 119.200/PR. Relator Ministro Dias Toffoli, Primeira Turma, julgado em 11.2.2014.

. Supremo Tribunal Federal. Recurso Ordinário em Habeas Corpus n. 118.977/ MS. Relator Ministro Dias Toffoli, Primeira Turma, julgado em 18.3.2014.

. Supremo Tribunal Federal. Habeas Corpusn. 126.315/SP. Relator Ministro Gilmar Mendes, Primeira Turma, julgado em 15.9.2015.

. Superior Tribunal de Justiça.Habeas Corpus n. 338/967/SP. Relator Ministro Nefi Cordeiro, Sexta Turma, julgado em 18.2.2016.

. Superior Tribunal de Justiça. Recurso Especial n. 1160440/MG. Relator Ministro Rogério Schietti Cruz, Sexta turma, julgado em 17.3.2016.

- Superior Tribunal de Justiça.Recurso Ordinário em Habeas Corpus $n$. $\overline{66.436 / S P}$. Relator Ministro Felix Fischer, Quinta Turma, julgado em 12.4.2016.

. Superior Tribunal de Justiça. Habeas Corpusn. 362.654/SP. Relator Ministro 
Reynaldo Soares da Fonseca, Quinta Turma, julgado em 5.5.2016.

BUSATO, Paulo César. Antecedentes, reincidência e reabilitação à luz do princípio de culpabilidade. Ciência Jurídica, Belo Horizonte, v.22, n.143, p. 302-316, set./out.2008.

CAPEZ, Fernando. Curso de direito penal: parte geral. v. 1. 20. ed. São Paulo: Saraiva, 2016.

COSTA, Álvaro Mayrink da. Direito penal: volume 3 - parte geral. 7. ed. rev. atual. e ampl. Rio de Janeiro: Forense, 2007.

DELMANTO, Celso; et al. Código penal comentado. 7.ed. rev. atual. e ampl. Rio de Janeiro: Renovar, 2007.

GRECO, Rogério. Curso de direito penal. 18. ed. Rio de Janeiro: Impetus, 2016.

LEITE FILHO, Nelson. Antecedentes criminais. Revista dos Tribunais.São Paulo, RT, v.778, ago. 2000, p. 489-492.

MIRABETE, Julio Fabbrini. Manual de direito penal: parte geral. v. 1.29 ed. rev. e atual. São Paulo: Atlas, 2013.

NUCCI, Guilherme de Souza. Manual de direito penal. 11. ed. rev. atual. e ampl. Rio de Janeiro: Forense, 2015.

PACELLI, Eugênio; CALLEGARI, André. Manual de direito penal: parte geral. São Paulo: Atlas, 2015.

PRADO, Luiz Regis. Curso de direito penal brasileiro. 14. ed. rev. atual. e ampl. São Paulo: RT, 2015.

QUEIROZ, Paulo. Direito penal: parte geral. 5. ed. rev. e ampl. Rio de Janeiro: Lumen Juris, 2009.

SANTOS, Juarez Cirino dos. Direito penal: parte geral. 3. ed. Curitiba: ICPC; Lumen Juris, 2008.

Artigo recebido em 16/06/2016

Artigo aprovado em 28/07/2016 